\title{
Statement from Sub-Committee on Teacher Education and Special Education
}

\author{
OCTOBER, 1980
}

\author{
J. C. P. Duerdoth, Convenor
}

\section{INTRODUCTION}

1.1 The 1970s have seen changes in special education which are reflected in special education teacher preparation programmes at colleges and universities. Among these changes has been a shift in emphasis from a categorical labelling and placement of exceptional children in segregated educational settings, to a non-categorical approach to special education which places a greater emphasis on the integration of eligible exceptional children in the regular school.

1.2 The area of concern for special education has moved from a traditional emphasis upon the education of category-specific handicapped children in segregated special schools, and now encompasses a broader dimension. The increasing range of special education is outlined in the Schools Commission : Report for the Triennium, 1976 - 1978 (June, 1975):

'Special education ... concerned ... with the education of children assigned to special schools, units and classes... with giving support within schools and classrooms to enable a gradually increasing proportion of children who are presently segregated to be educated with their peers... with the preparation of teachers to enable them to individualize the operations of the normal classroom, so that children who might in other circumstances have been in a segregated situation may be provided for within it.' (P. 235)

1.3 With an increase in the numbers of children being identified as in need of special attention in regular schools (Schonell - 12\% plus $2 \%$ having an identifiable handicap) greater demands have been placed upon training institutions to meet this demand.

1.4 There has been support by Departments of Education in all Australian States and Territories to expand special education services to include services to the regular schools. Such a change in emphasis from the traditional categorical segregated placements for exceptional children has meant that decisions about exceptional children are now more likely to be made after consideration of their educational needs rather than on the basis of medically derived disability labels.

1.5 Accompanying the trend towards the provision of education for the exceptional child in the regular school has been an increase in the number of teacher education courses to prepare teachers to work with exceptional children in an increasing number of regular education settings.

1.6 In many states there has been an increasing demand for teachers to work with severely and profoundly handicapped children and adolescents in school and institutional settings.

1.7 These changing trends have left all Australian States and Territories in a situation where the number of teachers trained in special education is inadequate to meet the demands of an expansion of services both within segregated educational settings and within the regular school for those children identified as in need of special education, and those children integrated into the ordinary school.

\section{AN OVERVIEW OF SPECIAL EDUCATION TEACHER TRAINING}

2.1 Teacher training in special education can be separated into two areas:

1. Pre-service education for general teacher trainees. (This includes pre-service specialization in Special Education)

2. In-service (post-service and postgraduate) education courses which are designed to equip a teacher to work in a special education setting, e.g. special school, special class or unit, or a support teacher in a regular school.

2.2 The growth of the practice of integration of exceptional children into the regular school has resulted in some pre-service teacher training courses including compulsory or optional units on the education of exceptional children. The inclusion of such units is supported by all recent reports on teacher education and reports on special education.

2.3 Since 1970, there has been an increase in the number of institutions offering courses for the initial preparation of teachers for special education. Some courses have a 
broad base aiming at servicing all areas of special education, while other courses follow the more traditional preparation of teachers for category-specific educational settings.

\section{DEVELOPING ROLES IN SPECIAL EDUCATION}

3.1 The increase of knowledge in the area of special education, and the changing social consciousness and educational philosophy, has meant a broadening of the definition of special education and, hence a demand by employers and professional groups for a more diverse teacher preparation programme.

3.2 Within special education demands are placed on teacher education courses to give high levels of skills and expertise necessary for teachers to work effectively in the following range of educational settings:

(i) In traditional special schools and units for the hearing impaired, visually impaired, physically and orthopaedically handicapped and the intellectually handicapped.

(ii) As a resource teacher, or a teacher of special class in a regular school, both at primary and post-primary levels.

(iii) As a teacher of multiply handicapped children.

(iv) With severely and profoundly handicapped people of all ages.

(v) With the socially disadvantaged and the emotionally disturbed.

(vi) In early intervention programmes.

(vii) As a team member in a multidisciplinary setting, expecially in institutions.

3.3 It is unrealistic for employers to expect all teachers to have all the skills and competencies necessary for all areas listed under 3.2.

3.4 Many special education teachers are also expected to act as consultants to parents, teachers and other professionals, and skills in these areas demand a higher level of training.

3.5 At present in most States the initial preparation of teachers for special education is provided by one-year full time PG1 courses.

3.6 The AASE supports the statement of the Survey of Special Education in Australia -

'That all teachers in special schools, and those working with the handicapped in regular schools, hold a recognised preservice award as well as additional specialist training, and the minimal requirements to teach in special education be three years of general teacher education and one year of special education preparation.' (p.304)

3.7 To enable these many requirements to be met, heavy demands are placed upon both lecturing staff and students and, because of the skill and expertise required by teacher educators, more favourable staff/student ratios are essential.

\section{PRE-SERVICE TRAINING}

4.1 The AASE policy statement (9.2) on teacher education at the pre-service level states:

'That the Association advocates the inclusion of compulsory units in Special Education, within all accredited preservice teacher education courses at early childhood, primary and postprimary level. Such cumpulsory units should prepare all teachers with minimum competencies in the understanding, knowledge and instruction of children with special education needs, whom they will encounter in the regular classroom.'

4.2 Recent reports on teacher education and special education support units in special education at the pre-service level, but at present there is no concensus on the content of such courses.

4.3 Recommendation - Pre-Service Education:

'That compulsory units on the education of exceptional children, with appropriate content and emphasis, be included in all accredited pre-service courses at early childhood, primary and post-primary levels, and that a pass in this unit be mandatory for teacher registration.'

4.4 The AASE could attempt to collate and then publish what it considers is 'appropriate content and emphasis' for preservice courses on special education and exceptional children.

\section{AREAS OF CONCERN OF SPECIAL EDUCATION TEACHER EDUCATORS}

\section{$5.1 \quad$ Funding}

5.1.1 The AASE is concerned about funding at two levels: 
(i) A reduction of funding available for the release of teachers to undertake special education on-campus courses. This has led to a decrease in enrolments but not a decrease in demand for these courses.

(ii) The funding of institutions involved in the provision of special education courses. As has been shown, employer expectations and demands are rising and more than a maintenance funding programme is required if special education courses are to meet the demands.

\subsubsection{Additional funding is required to -}

(a) provide opportunity for teacher educators in special education to promote and enhance continued development of their courses at a national level, and

(b) encourage institutions to undertake research to overcome the sparse data base from which decisions in special education are made in Australia.

\subsubsection{Recommendations:}

1. That continued funding be assured to enable the release of teachers to undertake special education courses.

2. That those colleges and universities which presently offer recognized qualifications in special education be assured of continued funding at an appropriate level to maintain and expand the quality of their staff, teaching function and research.

\subsection{Rationalization of Courses}

5.2.1 There needs to be a rationalization of special education courses, particularly courses for low incidence handicaps, to maintain quality special education teacher preparation programmes. However, the needs of teachers in country areas must be considered in any rationalization.

\subsection{Correspondence Courses}

5.3.1 For a variety of reasons many excellent teachers are unable to contemplate enrolment in full-time or part-time oncampus courses in special education and, because of the dearth of trained special educators, other modes of course presentation have to be considered and colleges are being forced to move to offcampus courses. On-campus courses, either full or part-time are considered more desirable for the intital preparation of special teachers.

5.3.2 While the Association believes on-campus studies in special education are essential for low-incidence handicaps, it does recognise that appropriately organized off-campus studies with appropriate supervised practicum experiences and on-campus vacation schools are an alternative for the training of teachers to work with the mildly handicapped.

\subsection{Untrained Teachers in Special Education}

5.4.1 The AASE is concerned at the number of teachers working in special education settings without formal special education qualifications (as outlined in 3.6). Exceptional children should not be further disadvantaged by being denied appropriately trained teachers.

5.4.2 The AASE supports the following statement from the Survey of Special Education in Australia.

'7.2 That teachers presently employed in special education who do not possess this minimal level of training (as outlined in 7.1) be given the opportunity to upgrade their qualifications by release to attend courses appropriate to their needs, such courses to include a full-time component in order that appropriate practical field experience may be undertaken (p.304).'

\subsection{In-Service Education}

5.5.1 There is a need for in-service programmes in special education for regular classroom teachers who are assuming responsibility for an increasing number of children who require special instruction.

5.5.2 Such in-service courses may be given credit towards formal special education qualifications.

5.5.3 In PG1 courses other than special education courses, there should be the capacity for students to undertake options of a special education nature. Such special education options should also be available for teachers upgrading a Diploma of Teaching to a Bachelor of Education status, and should be available both on-campus and off-campus. Optional units would be beneficial to those regular classroom teachers assuming responsibility for children who require special instruction.

\subsection{Teacher Aides in Special Education}

5.6.1 There is an urgent need to establish courses for training teacher aides for special education.

5.7 Consultancy Skills and Special Education Administration 
5.7.1 Many teachers working with exceptional children are expected to develop more complex roles as teachers, administrators and consultants.

5.7.2 Skills and competencies in the areas of administration and consultancy skills require a background of experiences, and there is a need to develop courses which specialize in consultancy skills and special education administration. Such courses would require an initial special education qualification and may best be presented at a Masters level (PG2). Courses for administrators would need to cater for both school administrators and for personnel in senior levels in the administration of special education.

\subsection{In-Service for Special Education Teacher Educators}

5.8.1 Concern is expressed at the quality of personnel preparing special education teachers and provision needs to be made to ensure a continual upgrading of special education teacher educators.

5.8.2 Provision for up-grading could be undertaken by:

1.Funds being available for intensive inservice workshops for teacher educators at a national level.

2 . The establishment and support of higher degree programmes of superior quality where teacher educators can undertake programmes.

3. Special education teacher educators must be encouraged to maintain close contact with schools and services for exceptional children and laboratories or training schools need to be located near colleges and universities.

\subsection{Multiply Handicapped and Profoundly Handicapped Children}

5.9.1 Of concern is the present lack of quality, structured courses to prepare teachers to work in the area of profoundly handicapped and multiply handicapped children and adolescents. 